\title{
Necrotizing fasciitis - a rare complication following common obstetric operative procedures: report of two cases
}

This article was published in the following Dove Press journal:

International Journal of Women's Health

7 April 2015

Number of times this article has been viewed

\author{
Robin Medhi \\ Suditi Rai \\ Arpana Das \\ Mansur Ahmed \\ Banani Das \\ Department of Obstetrics and \\ Gynaecology, Silchar Medical College \\ and Hospital, Silchar, Assam, India
}

\begin{abstract}
Necrotizing fasciitis, a near-fatal soft-tissue infection complicating obstetric operative wounds, is a rare entity in obstetrics. Herein, we report two cases of necrotizing fasciitis in severely undernourished and anemic women following obstetric operative procedures. Both undernourishment and anemia compounded the already existing immune-suppressed state in pregnancy and may have lead to life-threatening necrotizing fasciitis. One of the patients developed necrotizing fasciitis following episiotomy and the other following cesarean section. Both the cases were diagnosed clinically. Management was done by total parenteral nutrition, prompt correction of anemia, and surgical debridement under broad-spectrum antibiotic coverage. The raw areas were later reconstructed by split skin grafting in the first case, whereas, in the second case, due to the patient's refusal of skin grafting, the wound was allowed to heal by secondary intention. Both patients survived, although with morbidity. Our study aims to emphasize prompt correction of comorbidities along with aggressive management of necrotizing fasciitis for better outcomes in the obstetric population. Prompt correction of nutritional status improves the survival rate.
\end{abstract}

Keywords: anemia, undernourishment, total parenteral nutrition

\section{Introduction}

Necrotizing fasciitis (NF) is a rare disease of superficial fascia and subcutaneous tissue which may take a fulminating course with systemic toxicity and a high mortality rate. ${ }^{1}$ Incidence of NF following obstetric operative procedures is unknown. It often starts following trauma and, rarely, a surgical procedure. ${ }^{2,3}$ NF in the obstetric population, though rare, has a more ominous outlook than non-obstetric NF. ${ }^{4-7}$ Various microbial agents have been incriminated in the pathogenesis of NF, with existent literature reporting a variety of Gram-positive and Gram-negative aerobic and anaerobic organisms. ${ }^{8,9}$ The scenario in the obstetric population is further complicated by associated comorbidities such as diabetes mellitus, malnutrition, anemia, and intravenous substance abuse., ${ }^{4,5}$

Of these comorbidities, undernourishment and anemia are highly prevalent in developing countries. Poor nutritional status may negatively impact the outcome of NF. The association of undernourishment in pregnant women with NF and its impact on the prognosis of NF has not been discussed adequately in the obstetric literature. Prompt correction of nutritional status improves the survival rates in these patients. ${ }^{10}$ Our study aims to highlight the risk of NF in undernourished and anemic women during the postpartum period following operative intervention. Rapid correction of severe undernourishment and anemia by total parenteral nutrition and blood transfusion is vital for successful management.
Department of Obstetrics and Gynaecology, Silchar Medical College and Hospital,

Silchar, Gungoor, Assam, India

Pin 788014

Tel+9l 8252885933

Email suditirai.rims@gmail.com 


\section{Case reports}

\section{Case I}

An undernourished and anemic woman of 26 years old, gravida 3 para 2, presented to our hospital on the eighth postpartum day with extensive ulceration on the right side of the perineum following normal vaginal delivery with right mediolateral episiotomy done at a primary care center. According to the patient, she started experiencing severe excruciating pain over the episiotomy wound site from the fifth postpartum day. Along with pain, she also noticed swelling and redness over the area. Within the next 2 days, the skin over the area sloughed out, leaving behind a big ulcerated area over the perineum. The patient also had high fever with nausea, vomiting, and passage of loose stools.

At the time of admission, the patient looked pale, toxic, and dehydrated. Her temperature was $39.4^{\circ} \mathrm{C}$; pulse rate 120/minute; blood pressure $90 / 60 \mathrm{mmHg}$; and respiratory rate 24/minute. General health of the patient was poor, with body mass index (BMI) 12.8. On local examination, an ulcer of $12 \times 8 \mathrm{~cm}$ was seen over the right perineal area extending laterally to the inner aspect of the proximal one-fifth of the right thigh. The ulcer had an undermined edge, and the base of the ulcer was formed by granulation tissue with slough (Figure 1). It had purulent, foul-smelling, copious discharge. The ulcer had an inflamed surrounding without regional lymph node enlargement. The laboratory findings were hemoglobin $7 \mathrm{~g} / \mathrm{dL}$, total leucocyte count $20,000 / \mu \mathrm{L}$, total protein level $3.82 \mathrm{~g} / \mathrm{dL}$, serum albumin level $1.14 \mathrm{~g} / \mathrm{dL}$, serum creatinine $0.46 \mathrm{mg} / \mathrm{dL}$, random blood sugar $83 \mathrm{mg} / \mathrm{dL}$, serum sodium $130 \mathrm{mmol} / \mathrm{L}$, serum potassium $2.7 \mathrm{mmol} / \mathrm{L}$, and C-reactive protein $150 \mathrm{mg} / \mathrm{L}$. The Laboratory Risk Indicator for Necrotizing Fasciitis (LRINEC) score was 9, which is highly significant for NF.

Based on the clinical and laboratory findings, diagnosis of NF was made and the patient was immediately transferred to the intensive care unit. Aggressive medical and surgical management was undertaken. The patient was put on total

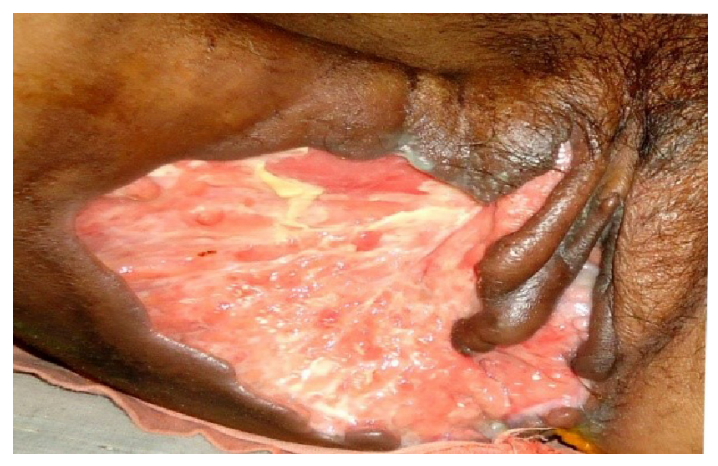

Figure I Necrotizing fasciitis complicating an episiotomy wound. parenteral nutrition and had two units of packed red blood cells transfused, and broad-spectrum antibiotics were started. At the same time, pus from the discharge site was sent for culture and sensitivity testing. Wide surgical debridement was commenced on the following day. The patient's pus culture report showed the growth of Proteus and Klebsiella spp. The patient was empirically started on intravenous antibiotics with piperacillin-tazobactam and gentamicin and, as the drug sensitivity report showed susceptibility to these antibiotics, the same was continued. Regular dressing of the wound was done for the next 4 weeks. The histopathological report confirmed the diagnosis of NF by showing necrosis of superficial fascia and subcutaneous fat, with dense infiltration of polymorphonuclear leucocytes and thrombosis of cutaneous vessels. Minimal enteral feeding was initiated on day 5 of the intensive care unit, and the patient was discontinued from parenteral nutrition on day 7 once $50 \%$ of the target nutritional requirement was achieved. Split skin grafting was done after 4 weeks, and the patient was discharged on the 42 nd day in good condition.

\section{Case 2}

A 37-year-old woman, para 3 with 2 living children, was referred to us from a private nursing home on the fifth day of puerperium with an extensive ulcer over the cesarean section wound. The patient had undergone cesarean section for fetal distress. The patient had fever and severe excruciating pain over the wound despite taking analgesics. This was accompanied by soakage of the bandage with copious discharge on the fifth postoperative day. At the time of admission, the patient was febrile, pale, and undernourished. Her vitals were temperature $38.3^{\circ} \mathrm{C}$, blood pressure $90 / 60 \mathrm{mmHg}$, pulse rate $110 /$ minute, and respiratory rate $22 /$ minute. Her BMI was 12.55. On local examination, a wide area of skin and superficial tissue surrounding the surgical site was found to be sloughed out. The ulcer had undermined edges with surrounding edema, induration, and redness, along with copious discharge (Figure 2). The abdomen was otherwise soft and non-tender, with presence of normal bowel sounds. Her laboratory findings were hemoglobin $6.8 \mathrm{~g} / \mathrm{dL}$, total leucocyte count $19,000 / \mu \mathrm{L}$, total protein level $4.1 \mathrm{gm} / \mathrm{dL}$, serum albumin level $1.14 \mathrm{gm} / \mathrm{dL}$, serum creatinine $0.68 \mathrm{mg} / \mathrm{dL}$, random blood sugar $106 \mathrm{mg} / \mathrm{dL}$, serum sodium $142.1 \mathrm{mmol} / \mathrm{L}$, serum potassium $2.69 \mathrm{mmol} / \mathrm{L}$, and C-reactive protein $27.6 \mathrm{mg} / \mathrm{L}$. The LRINEC score was 3.

Based on the clinical features, diagnosis of NF was made and the patient started on broad-spectrum antibiotics with Inj.piperacillin-tazobactum and Inj.gentamicin. Three units 


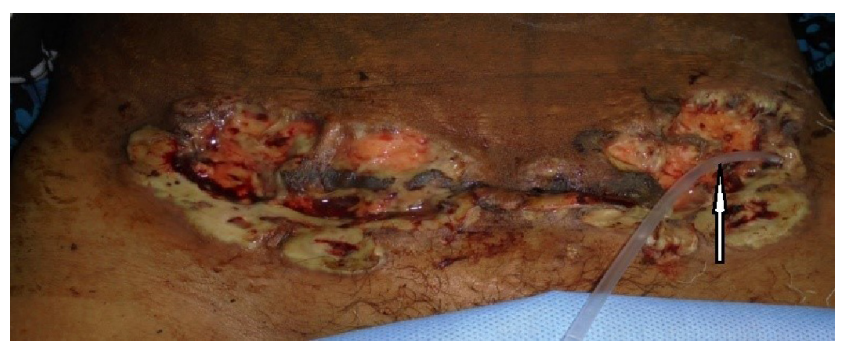

Figure 2 Necrotizing fasciitis complicating a cesarean wound.

Note: The arrow shows the undermined edge of the ulcer.

of packed red blood cells were transfused. Total parenteral nutrition was started to correct the nutritional status. Surgical debridement was done the day after admission and all the necrotic and dead tissue was removed, leaving behind a margin of healthy looking tissue. Pus was sent for culture and sensitivity testing and showed the growth of Proteus and Klebsiella spp. and susceptibility to the previously started antibiotics. The diagnosis was confirmed histopathologically. The patient was also gradually started on minimal enteral feed from the fourth day and parenteral nutrition was discontinued from the sixth day. As the patient refused skin grafting, regular dressing was done, and she was discharged after 47 days in an improved condition (Figure 3).

\section{Discussion}

NF is a dreaded soft-tissue infection caused by a variety of microorganisms. Its initial nonspecific clinical picture masks the impending disastrous course of the disease. The immune-suppressed state of pregnancy may be responsible for a rapid fulminant course and high mortality. ${ }^{3-6}$ To further complicate the picture, women in developing countries are faced with two more comorbid conditions: undernourishment and anemia.

Various predisposing factors described for NF in the obstetric population are diabetes mellitus, malnutrition, and intravenous substance abuse. In our study, undernourishment and anemia were found to be associated with NF. The diagnosis of severe undernourishment and anemia was made from very low BMI, and low serum total protein, serum albumin, and hemoglobin levels. Poor nutrition and concomitant

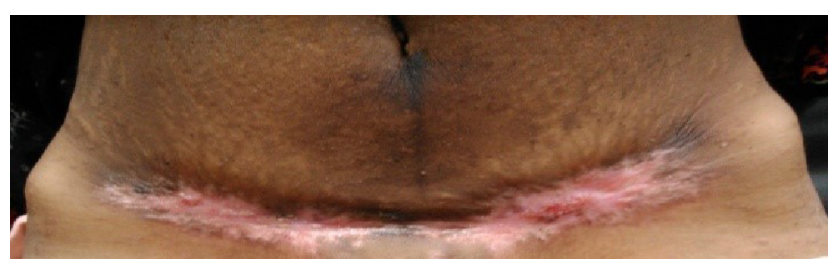

Figure 3 Healing of the cesarean wound by secondary intention (day 47). immune suppression play a crucial role by impairing the host's response to modulate the immune system and contain the infection. Cellular immunity is more compromised in undernutrition and presence of devitalized tissue at the site of the wound further increases the susceptibility manifold.

Severely anemic patients are more prone to developing infection. In patients with severe anemia, there is alteration of the proliferation of $\mathrm{T}$ and $\mathrm{B}$ lymphocytes, which causes reduction of the bactericidal activity of the phagocytes and neutrophils, hence rapid correction of severe anemia is required.

Bacteriology of the infection was polymicrobial in both cases, involving Klebsiella and Proteus spp. broad spectrum antibiotics started on empirical basis was found to be effective as reported in sensitivity pattern subsequently.

Initial presentation of NF is often mistaken for cellulitis or wound hematoma. Early local signs are edema, erythema, crepitus, fluctuation, and tenderness, which are nonspecific. As the disease progresses, the skin sloughs out rapidly, leaving an ulcer with undermined edges and copious discharge which may be malodorous. Suspicion of NF should arise with severe pain disproportionate to these local inflammatory findings and the appearance of signs of systemic toxicity.

The LRINEC score was developed by Wong et $\mathrm{a}^{11}$ for diagnosis of NF based on a scoring system, where scores are assigned for levels of C-reactive protein, hemoglobin, total leucocyte count, serum sodium, serum creatinine, and blood sugar. A score of 8 or more has a strong positive predictive value for diagnosing NF. The LRINEC score was 9 in case 1 and 3 in case 2. Probably due to previous antibiotics and intravenous fluid administration following cesarean section, the score was low in case 2 .

Incorporation of radiological imaging, computed tomography, and magnetic resonance imaging as diagnostic tools helps in early diagnosis and determining the extent of softtissue infection, and thereby the subsequent limit of surgical debridement. ${ }^{12,13}$ The spread of the disease process can be delineated by the presence of gas in the area visible radiologically well before clinical assessment of the tissue. ${ }^{13}$ However, availability and cost limit the applicability of CT scans and MRIs.

In both the cases, diagnosis of NF was made on clinical grounds. The LRINEC score was favorable in one case. The confirmation of diagnosis was done by microbiological and histopathological reports. Most physicians still have to depend upon the clinical presentation with a strong eye of suspicion and profound awareness of NF.

Although the key to successful management of NF is strong clinical suspicion and aggressive surgical debridement 
under antibiotic cover, women with undernourishment and anemia need further individualization. We successfully managed two cases of NF following episiotomy and cesarean section who presented with a double challenge of undernourishment and anemia by total parenteral nutrition and blood transfusion simultaneously. The study highlights the risk of NF in undernourished and anemic women during the postpartum period and also the importance of total parenteral nutrition and correction of the anemic state in successful management of NF.

Identification of risk factors for malnutrition should be part of antenatal visits, and patients with these factors should be categorized into the high-risk group. Significant risk to the health of a woman can be anticipated from their dietetic history and socioeconomic background, as these factors play a crucial role in the health statuses of women from low- and middle-income countries. In addition to the routine aspects, general physical examination should consist of BMI recording and observation for signs of vitamin and mineral deficiencies. Laboratory investigations should also include total serum protein and serum albumin levels. Remedial action should be taken at first contact and the patient followed up periodically.

\section{Disclosure}

The authors report no conflicts of interest in this work.

\section{References}

1. Rouse TM, Malangoni MA, Schulte WJ. Necrotizing fasciitis: a preventable disaster. Surgery. 1982;92:765-770.

2. Fallahzadeh H, Altenbernd E, Mays ET. Necrotizing fasciitis. Am Surg. 1974;40:352-354.

3. Defore WW Jr, Mattox KL, Dang MH, Crawford R, Jordan GL Jr. Necrotizing fasciitis: a persistent surgical problem. JACEP. 1977;6:62-65.

4. Lowthian JT, Gillard LJ Jr. Postpartum necrotizing fasciitis. Obstet Gynecol. 1980;56:661-663.

5. Golde S, Ledger WJ. Necrotizing fasciitis in postpartum patients. A report of four cases. Obstet Gynecol. 1977;50:670-673.

6. Roberts DB, Hester LL Jr. Progressive synergistic bacterial gangrene arising from abscesses of the vulva and Bartholin's gland duct. Am J Obstet Gynecol. 1972;114:285-291.

7. Lynch CM, Pinelli DM, Cruse CW, Spellacy WN, Sinnott JT, Shashy RG. Maternal death from postpartum necrotizing fasciitis arising in an episiotomy: a case report. Infect Dis Obstet Gynecol. 1997;5:341-344.

8. Elliott DC, Kufera JA, Myers RA. Necrotizing soft tissue infections. Risk factors for mortality and strategies for management. Ann Surg. 1996;224(5):672-683.

9. Sarani B, Strong M, Pascual J, Schwab CW. Necrotizing fasciitis: current concepts and review of the literature. J Am Coll Surg. 2009;208: 279-288.

10. Nolan TE, King LA, Smith RP, Gallup DC. Necrotizing surgical infection and necrotizing fasciitis in obstetric and gynecologic patients. South Med J. 1993;86(12):1363-1367.

11. Wong CH, Khin LW, Heng KS, Tan KC, Low CO. The LRINEC (Laboratory Risk Indicator for Necrotizing Fasciitis) score: a tool for distinguishing necrotizing fasciitis from other soft tissue infections. Crit Care Med. 2004;32:1535-1541.

12. Yu JS, Habib P. MR imaging of urgent inflammatory and infectious conditions affecting the soft tissues of the musculoskeletal system. Emerg Radiol. 2009;16(4):267-276.

13. Gallup DG, Freedman MA, Meguiar RV, Freedman SN, Nolan TE. Necrotizing fasciitis in gynecologic and obstetric patients: a surgical emergency. Am J Obstet Gynecol. 2002;187(2):305-310.
International Journal of Women's Health

\section{Publish your work in this journal}

The International Journal of Women's Health is an international, peerreviewed open-access journal publishing original research, reports, editorials, reviews and commentaries on all aspects of women's healthcare including gynecology, obstetrics, and breast cancer. The manuscript management system is completely online and includes

\section{Dovepress}

a very quick and fair peer-review system, which is all easy to use. Visit http://www.dovepress.com/testimonials.php to read real quotes from published authors. 